\title{
The Political Leadership Factor in the Spanish Local Elections
}

\author{
GuAdALUPE MARTINEZ Fuentes \& CARMEN ORTEGA Villodres
}

\begin{abstract}
The present research looks at personal following and voting in the Spanish local elections held in 2007. In doing so, the study addresses three principal questions, each focusing on a different dimension of the effects of political leadership on local voting. These are: What is the relative impact of leadership evaluation vis-à-vis other contingent and structural factors of a local, regional and national nature? What is the relative impact of the local party leaders vis-à-vis the leaders of the national and regional party strata? Do leadership evaluations count differently for voters politically identified with particular parties?
\end{abstract}

KEYWORDS: • political leadership • local elections $\bullet$ political parties • democracy $\bullet$ Spain

Correspondence AdDress: Guadalupe Martinez Fuentes, Ph.D., Department of Political Science and Public Administration, Faculty of Political Sciences and Sociology, University of Grenada, C/Rector López Argueta, s/n, 18071 Granada, Spain, email: gmart@ugr.es. Carmen Ortega Villodres, Ph.D., Department of Political Science and Public Administration, Faculty of Political Sciences and Sociology, University of Grenada, C/Rector López Argueta, s/n, 18071 Granada, Spain, email: cortega@ugr.es. 


\section{$1 \quad$ Leadership-Centred Local Elections?}

The broad eclectic literature on the role of political leaders at the apex of the parties and states has reiterated the existence of a trend of personalisation of political leadership within the institutional, partisan, and electoral arenas of the democratic political process (Ostrogorski, 1970; Weber, 1968; Michels, 1966; Mabileau, 1960; Cavalli, 1987, 1994; Edelmann, 1987; Sartori, 1989; Wattemberg, 1991; Bowler and Farrell, 1992; Fabbrini, 1999; Mughan, 2000; Ruscio, 2004; Poguntke and Webb, 2005).

This long-standing concern has progressively stimulated the development of a parallel academic production on electoral studies that take more into consideration the "political leadership factor" as a component of the formula that explains the outcome of electoral democracy (Kaase, 1994; McAllister, 1996; Curtice and Holmberg, 2005). Even so, electoral studies have rarely faced such a multifaceted research framework.

First of all, local elections have traditionally been considered 'second-order elections' and, consequently, have been treated as secondary research objects. In this line, while there has been much discussion on the growing significance of the leadership appeal in national elections, there has been less analysis of the incidence of personal following and voting in the local arena. Moreover, even if the influence of regional and national factors on the development and results of local elections is not to be denied, these elements have rarely been studied jointly in order to understand the political leadership behaviour factor within the local vote equation. Therefore, we do not know whether or not the electorate evaluates different political leadership phenomena when deciding its vote at the local electoral level. Furthermore, there is not enough knowledge to argue whether the impact of leadership evaluations varies among voters in local elections.

These general deficiencies are transferable to the specific stage of the research on the electoral effect of the political leadership factor in the Spanish local democracy. Whereas there is a growing interest in the respective importance of the role and the weight of parties, and party leaders in Spanish national elections (Rico, 2002; Biezen and Hopkins, 2005), there seems to be less interest in the magnitude of the electoral impact of these political actors at the local level. Moreover, the evidence offered by scholars on Spanish local government, e.g., Alba and Navarro (2003), and Magre (1999), on the Spanish local elections, e.g., Carrillo (1989), Delgado (1997), and Capo (1991, 1999), and on local political leadership in Spain, e.g., Vanaclocha (1997, 2005), Natera (1997, 2003), and Martínez-Fuentes (2008) does not tell a coherent story about this subject matter. Consequently, the accumulated knowledge on the value of the political leadership factor taken as an electoral determinant in the Spanish local arena is scarce, fragmented and dispersed. 
In this paper, the goal is to contribute to understanding this conundrum by identifying and fitting together some of its many pieces. To this end, the present research looks at the potential incidence of personal following and voting in the Spanish local elections held in 2007. In doing so, the study addresses three principal questions, each concerning different dimensions of the effects of the political leadership factor on local voting: What is the relative impact of leadership evaluation vis-à-vis other contingent and structural factors of local, regional and national nature? What is the relative effect of the local party leaders vis-à-vis the leaders of the national and regional party strata? Do leadership evaluations count differently for voters politically identified with particular parties? The answers to these questions are sought by reviewing speculative arguments both for and against the personalisation of following and voting in local elections (Section Two), and by presenting empirical evidence on the effects of leadership factors (Section Three). Finally, some reflections and conclusions are drawn on the subject matter (Section Four).

\section{The Spanish Municipal Elections: "Leadership-Centred Vote Choice?}

On the one hand, it is argued that in the Spanish local elections, the normal pattern for some form of national party politics is to prevail in the way the council seats are contested (Carrillo, 1989; Delgado and López, 1997; Vallés and Brugué, 2001). But on the other hand, it is maintained that Spanish local elections are held from a personalised and localist perspective (Botella, 1999; Capo, 1999; Magre, 1999; Vanaclocha, 1997, 2005; Natera, 1997, 2003; Márquez, 2007). This contradiction is not just a case of scholarly nitpicking. Researchers who differ in their conceptions of local electoral behaviour select different phenomena to focus on and to interpret the result in different ways.

\subsection{Partisan and Nationalised Municipal Elections}

Various arguments justify the idea that in Spanish municipal elections, evaluations about national and regional party politics prevail over assessments of local affairs. One argument is that since the municipal electoral contests and regional parliamentary elections are held simultaneously ${ }^{1}$, most national parties run integrated campaigns covering both the Regional Parliament and Local Government election campaigns. Faced with this parallel campaigning, the local organisations of these parties act as 'private recruitment agencies' to take advantage of the national party's ground by putting forward the party's local candidates, and as 'private marketing agencies' to communicate party ideology by translating national or regional party policies into specific local issues. Another argument is that the simultaneous convocation of municipal election contests and regional parliamentary elections encourages voters to line up in a broadly similar way to the choices they make in local and regional parliamentary elections. 
Apart form this, the Spanish Electoral System Act of 1985 (LOREG) and the previous and current Party Financing Acts of 1987 and 2007 (LOFPP) give consolidated political parties privileged marketing and credit concessions for campaigning. Given that campaigning for local government is progressively becoming large-scale, the electoral possibilities of local candidatures backed by these national parties increase, whereas opportunities for emerging local candidatures is conversely limited. Indeed, 70 per cent of the candidatures presented for the local election as a whole belong to the national parties PSOE (Socialist Party), PP (Popular Party), and IU (United Left) (Vallés and Brugué, 2001). Hence, the hegemonic electoral offer of the national parties impel the local electorate to contemplate the municipal electoral competition in national and partisan terms, voting in line with this, and as a result, reinforcing the nationalised nature of the local party system (Delgado and López, 1997; Navarro, 2002).

Additionally, the local electoral system (first regulated by the Local Authorities Act of 1978 and later by the Spanish Electoral System Act of 1985) also promotes the partisan nature of elections. Spanish municipalities use two different electoral models depending on the municipality size. Municipalities with more than 250 inhabitants have a closed list system (Alba and Navarro, 2003: 208; COR, 2004). It follows the D'Hondt formula to allocate seats in the municipal council. For their part, the smallest municipalities (between 100 and 250 inhabitants) have an open list system, but it actually works as a closed one (Alba and Navarro, 2003: 208). Consequently, the election of the candidates for the Spanish mayoralties lies in the political party's decisions and nominations of candidates, whereas the electorate sees the margin of its choice limited. Hence, under these conditions, the elector's loyalty to the party is expected to prevail over his/her likes or dislikes about the candidate nominated for mayoralty by the party organisation.

\subsection{Personalised and Localist Municipal Elections}

A different focus on the local electoral system and local political behaviour may lead to a different conception and interpretation of the nature of the Spanish municipal elections. Indeed, that is the viewpoint of those researchers who defend the existence of an important trend of 'presidentialisation, personalisation, and localisation' in local elections in Spain.

Their primary argument that sustains the ideas of localisation and personalisation of local elections is based on the consideration of the localist and personalised nature of the local electoral offer itself. In this line, they argue that in spite of the fact that national parties usually impose homogeneous campaigning strategies for national, regional and local electoral competitions, at the end of the day, the local campaign follows the local candidate criterion by focusing on the very particular and local aspects of political life. It has much to do with the specific structure of the local party system (Márquez, 2007). By the same token, it is pointed out that 
despite the candidatures of the national parties prevailing in the municipal contests, minor local candidatures - like those identified as 'splinter' parties or 'independents' deliberately avoiding party labels (Van der Kolk, 2007) - find a small but privileged opportunity at the local level. Moreover, what these candidatures generally have in common is that they are based in a specific municipality with a specifically local focus, but they are also organised around a popular and charismatic leader (Delgado and López, 1997; Natera, 2001). More to the point, it is maintained that this consideration about the "leadership-centred" nature of such minor candidatures could even be extended to the local candidatures supported by national parties. Since PSOE and PP behave as catchall and cohesive parties that generally promote "leadership-centred" campaigns (Costa Lobo, 2008), most campaigning efforts within these parties are dedicated to publishing and endorsing the political figure at the head of the party candidature as the party aspirant for mayoralty.

Furthermore, the premise of personalisation of the local electoral offer is strengthened by considering the 'soft presidential' model of government institutionalised in the local Spanish arena. In this regard, scholars on the Spanish local government argue that the political power, concentrated in the Spanish mayoralty through formal and informal institutional procedures, makes the Spanish local political system follow the "strong-mayor form" (Mouritzen and Svara, 2002), thereby providing the local authorities with the "mayor-driven executive and assembly" model of behaviour if the mayor's party dominates within the local party system (Martínez-Fuentes, 2008). Needless to say, this makes the distinct parties conceive the local election as a contest for the presidency of local government, and hence, they carefully select and intensively promote their candidate for "president".

The third argument to defend the localist and personal character of the municipal elections is found by considering the localist and personal nature of the electoral demand itself. Its localist facet derives from the presence of the splinter vote phenomenon. That is to say, there are citizens who participate in local elections by supporting a party candidature that they would not otherwise endorse for election at upper levels of government. For its part, the personal following and voting premise lies in the consideration of the degree of proximity, confidence, knowledge, and even in the clientele that presides over the interaction between the electorate and the candidates for local government (Vanaclocha, 2005; Robles, 2005). Since this interaction is much more personalised than the relation generally sustained between the voters and the candidates in regional and national elections, the personal component of the vote choice is expected to be more decisive in municipal elections than in regional or national contests. More to the point, this trend is reinforced by the local electoral system itself. Since this system allows just the single heads of the party candidatures to aspire to mayoralty, the competition between the candidatures for local government is in practical terms 
reduced to the competition between their leaders. In the same way, the electorate's consideration of the different electoral options is practically limited to the evaluation of these party leaders. Finally, in the same way that the soft presidential model of local government leads the parties to understanding and planning the local elections in presidential and personalised terms, this power distribution within local government also provides an incentive for voters to consider their vote in presidential and personal terms.

\section{Testing the Vote Choice in the Spanish Municipal Elections}

The aforesaid general conditions of the Spanish local elections are transferable to the Andalusian local elections. That is to say, the contemplation of the institutional model of the Andalusian local governments, the normative elements of the local electoral system used in the region, the nature of the political parties competing in the Andalusian local arena, and the general pattern of local political behaviour of the Andalusian electorate may lead to criticism and support for the localisation/personalisation and partisanship/nationalisation approaches. However, the observation of the political and electoral specificities of the region provides further arguments both for and against these postures.

\subsection{The Andalusian Case Study}

The first Andalusian particularity to be observed within the "localisationnationalisation" debate concerns different levels of participation registered in national, regional, and municipal elections (Table 1). Local elections do not mobilise the Andalusian electorate as much as national and regional elections do. And this pattern of electoral behaviour, generalised in all Spanish regions, has often led to considering local elections as second-order contests (Montero,1988). In the subsidiary character of these elections, many find a reason to argue about the electorate's propensity to subordinate local electoral politics to national political life. However, others do not interpret this issue in terms of nationalisation, but rather as a question of differentiation and particularisation of municipal contests.

The second question under discussion refers to different levels of vote concentration respectively registered in the national, regional, and local elections held in Andalusia (Table 2). The degree of vote choice concentration around the first and second major parties is significant in all cases. In municipal elections, this indicator is appreciably lower than in other casuistries. In this regard, there are two possible and opposing interpretations. The first one relates to the noteworthy concentration of the Andalusian local electoral references around the PSOE and PP. In view of this fact, the prevalence of the local candidatures of these national parties is considered as an indicator of the nationalisation of the local vote choice. But on the contrary, the second interpretation justifies the localisation of the vote 
choice on the basis of two interrelated observations. First, in municipal elections, minor parties conquer wider electoral spaces than in national and regional contests. Second, local contests represent the only electoral opportunity of localist candidatures to have a chance to become institutionalised political organisations.

Regarding the "personalisation and partisanship" debate, the first issue to highlight is the variation in the vote between national, regional, and local elections (See table 2). Since the very beginnings of the Spanish process of political decentralisation, Andalusia became the Socialist Party's richest vote field (Cazorla, 1991; Montabes, 2002; Montabes and Ortega, 2006). To date, the PSOE has always been the most highly supported party in the national, regional, and municipal elections at the aggregate level.

However, despite the fact that in municipal elections, this party wins a majority of ballots, its electoral gain at the local level is usually poorer than its national or regional electoral winnings. Not surprisingly, the observation of this phenomenon entails a twofold understanding. On the one hand, many believe that the general pattern in local elections is for some form of party identification to prevail in the way council seats are contested. But on the other hand, focussing exclusively on the relative weakening of the Andalusian electorate alignment with the PSOE in local elections, others argue that this moderate split or dual voting phenomenon constitutes a signal of the personal - and even localist - perspective that the electorate makes on its vote for the municipal government. In this line, the supporters of this approach maintain that in local elections, electors have an accurate knowledge of mayoralty candidates. Hence, they value the candidates' managerial capacities and political abilities (in addition to the social compromise for leading the local community to a greater extent) more than the candidates' ideological inclinations or party affiliation.

Finally, the discussion on the effects of partisanship and personalisation on the local vote choice is also based on insignificant variations of the vote orientation between consecutive municipal elections (see Table 3). This result is usually associated with the defence of the electoral prevalence of the party identification factor, and with the refutation of the electoral centrality of the political leadership factor. However, such a result could equally be associated with the long-standing nature of the local political leadership in Andalusia, and hence, it serves as an indicator of the predominance of personal following and voting.

\subsection{Data, Model Specification and Measurement}

In view of the arguments and counter-arguments provided by these two different approaches, it is worth stating that local elections in Spain are neither a mere reproduction of the electoral processes held at national and regional levels nor completely disconnected to national and regional electoral trends (Botella and 
Capo, 1997). In this line, it is equally analytically relevant to acknowledge that both parties and party leaders play an important role in the local elections, and hence, party alignments and leader evaluations may equally influence the decision-making vote. Furthermore, it is ultimately important to recognize that studying the Spanish local vote choice demands that researchers adopt an open point of view that allows them to focus on interdependence between these factors. Specifically, this is the approach of the present analytical study.

Since in the local elections held in Andalusia most electoral preferences concentrate around the PSOE and PP options, the study focuses on the motivations that lead the PSOE and PP voters to support these candidatures. Hence, the PSOE and PP vote choices are considered as dependent variables. Both of them are considered to be a function of a long list of explanatory variables that are systematised by their very temporal nature within three different categories that are temporally coordinated. In this way, these are catalogued as factors that affect voters' predispositions in the long-term, mid-term, or short-term (see Table 4).

In view of the fact that partisan and ideological attitudes are learnt during early adulthood and remain relatively stable thereafter (Alwin and Krosnick, 1991), voter proximity to parties and the voter's party identification are used in this study as the main long-term explanatory variables of the PSOE and PP vote choice. Contingent and structural circumstances occurred and persisted throughout a significant four-year period of local legislature. In this study, they are considered as mid-term explanatory factors. Finally, the short-term explanatory variables contemplated in this work concern the party leaders during election campaigns.

Regarding the final evaluation of these research results, it must be said that the study findings imply the verification of the mixed partisan, personalised, and localist character of the Spanish municipal elections. In Andalusia, the electorate saw the 2007 local elections from personalised, localist, and presidential perspectives. However, whereas local leaders and local campaigns were determinants for those undecided or weakly aligned with the parties in competition, party politics prevailed in the way council seats were contested by those electors who strongly identified themselves along partisan lines. In this way, the local political leadership factor had a significant value within the vote equation, but not enough to surpass the electoral value of party loyalties.

\section{Discussion}

Probably the most outstanding symptom of the long-standing concern about the importance of leadership in democratic politics is the fact that the leadership studies in the context of democratic elections have gradually become a subset of electoral studies. These studies increasingly take into account the "political leadership factor" as a component of the formula that explains vote choice, thus 
enriching the rationalisation of the outcome of electoral democracy. However, there is still a long way to go to fully understand the impact that the political leadership factor makes on the development and results of electoral contests because the nature, conditions and degree of the leaders' electoral influence are not yet clear in sub-national levels of government. Therefore, further research is needed to clarify these points.

Notwithstanding the complexity entailed in pursuing such an objective, the present study aimed at making a small step along this interesting and fruitful path of research. In doing so, it explored the field of the Spanish local elections, centring its attention on the role played by local political leaders in the municipal elections held in Andalusia in May 2007. As a result, it offered an inclusive view of the behaviour of the political leadership factor with the vote choice equation of the Andalusian electorate, explaining its relative value vis-à-vis local, regional and national structural or contingent factors, and other regional and national leadership phenomena.

The research findings suggested that in Andalusia, the electorate saw the 2007 local elections from the personalised, localist and presidential perspectives. In addition, it pointed out that whereas evaluations of local leaders were determinants for those undecided or weakly aligned with the parties in competition, party politics prevailed in the way the council's seats were elected by those electors who strongly acted along partisan lines. Finally, we can say that the Spanish local political system is based upon a legal framework and a political culture in which both parties and party leaders are visible and influential.

Now, the challenge is to determine whether this behaviour is reproduced in other Spanish contexts or not, and whether this really matters for the functioning of local democracy. That is why the discussion of this study cannot avoid concluding by suggesting that extensive studies, covering other Spanish regions, can give political scientists and politicians a deeper insight into both the local electoral behaviour of the Spanish electorate and local governance in Spain. Regarding this, it is worth making a final research qualification. Caution is needed when interpreting the results of this study because research methodologies are still tentative and unpolished. Hence, it is essential to consider how the existing political science methods can be adapted to capture and measure (in a more comprehensive way) the political leadership behaviour factor in a multilevel electoral system. In this sense, the combination of quantitative and qualitative methodological resources is recommended because it could provide promising data for comprehensive analyses. 


\section{Notes}

${ }^{1}$ This rule is not applied in the Basque Country, Galicia, Catalonia, and Andalusia.

\section{References}

Alba, C. \& Navarro, C. (2003) Twenty-five years of democratic local government in Spain, In: Kersting, N. \& Vetter, A. (eds.) Reforming Local Government in Europe: Closing the Gap between Democracy and Efficiency (Opladen: Leske + Budrich), pp. 197-220.

Bartle, J. (2004) Partisanship, performance and personality: competing and complementary characterizations of the 2001 British general election, Party Politics, 9(3), pp. 317- 345, doi: $10.1177 / 1354068803009003003$.

Bean, C. (1990) The Personal Vote in Australian Federal Elections, Political Studies, 38(2): 253268, doi: 10.1111/j.1467-9248.1990.tb01491.x.

Bowler, S. \& Farrell, D.M. (1992) Electoral Strategies and Political Marketing (London: Macmillan).

Cain, B., Ferejohn., J. \& Fiorina, M. (1987) The Personal Vote: Constituency Service and Electoral Independence (Cambridge: Harvard University Press).

Capo. J. (1991) Elecciones municipales, pero no locales, Revista Española de Investigaciones Sociologicas, 56(91), pp. 143-164.

Capo, J., (1999) El debate sobre el sistema electoral local. Imágenes, intereses y propuestas, In: Botella J. (coord.), La ciudad democrática (Barcelona: Ediciones del Serbal), pp. 91-114

Carey, J. M. \& Shugart, M. S. (1995) Incentives to Cultivate a Personal Vote: A Rank Ordering of Electoral Formulas, Electoral Studies 14(4), pp. 417-439, doi: 10.1016/02613794(94)00035-2.

Carrillo, E. (1989) La nacionalización de la política local, Política y Sociedad, (3), pp. 29-46.

Cavalli, L. (1987) Potere oligarchico e potere personale della democrazia moderna, In: Cavalli, L. (ed.), Leadership e Democrazia (Padova: CEDAM), pp. 3-42.

Cavalli, L. (1994) The personalization of Leadership in Italy, Paper presented at the XVI World Congress of the International Political Science Association. Berlin, August, 21-25, 1994.

Cazorla, J. (1991) Resultados electorales y actitudes políticas en Andalucía, Revista Española de Investigaciones Sociológicas, 56, 7-33.

Costa Lobo, M. (2008) Parties and leader effects. Impact of Leaders in the Vote for Different Types of Parties, Party Politics, 14(3), pp. 281-298.

Curtice, J. \& Holmberg, S. (2005) Party leaders and party choice, In: Thomassen, J. (ed.), The European voter: a comparative study of modern democracies (Oxford: Oxford University Press).

Delgado, I. \& López, L. (1997) Las Especificidades de las Arenas Electorales Municipales, In: Alba, C. \& Vanaclocha, F. (eds.) El Sistema Politico Local: Un Nuevo Sistema de Gobierno, (Madrid: Universidad Carlos III de Madrid y Boletín Oficial del Estado). pp. 247-75.

Dinas, E. (2008) Big expectations, small outcomes: The impact of leaders' personal appeal in the 2004 Greek election, Electoral Studies, 27(3), pp. 505-517.

Edelmann, M. (1988) Constructing the political spectacle (Chicago: University of Chicago Press).

Elgie, R. (1995) Political Leadership in Liberal Democracies (New York: Palgrave Macmillan).

Fabbrini, S. (1999) Il Principe democratico. La leaderbip nelle democrazie contemponanee (Rome: Editori Laterza).

Gaines, B. J. (1998) The Impersonal Vote? Constituency Service and Incumbency Advantage in British Elections, 1950-92, Legislative Studies Quarterly, 23(2), pp. 167-95.

Kaase, M. (1994) Is there personalisation in politics? Candidates and voting behavior in Germany, International Political Science Review, 15(3), pp. 211-230, doi: 10.1177/019251219401500301.

Katz, R. S. (1986) Intraparty Preference Voting, In: Grofman, B. \& Lijphart, A. (eds.) Electoral Laws and Their Consequences (New York: Agathon Press), pp. 85-103. 
Krashinsky, M. \& Milne, W. J. (1986) The Effect of Incumbency on the 1984 Federal and 1985 Ontario Elections, Canadian Journal of Political Science, 19(2), pp. 337-343.

Magre, J., (1999) La estabilidad municipal a través de la figura del alcalde, In: Botella, J. (Coord) La ciudad democrática (Barcelona: Ediciones del Serbal), pp. 115- 136.

Martínez-Fuentes, G. (2008) Local Political Leadership in Spain, Local Government Studies, 34(2), pp. 267-278.

Márquez, G., (2007) Política y Gobierno Local. La formación de gobierno en las Entidades locales en España (Madrid: Centro de Estudios Políticos y Constitucionales).

Marsh, M. (1985) The Voters Decide? Preferential Voting in European List Systems, European Journal of Political Research 13(4), pp. 365-378, doi: 10.1111/j.1475-6765.1985.tb00132.x.

Marsh, M. (2008) Candidates or Parties? Objects of Electoral Choice in Ireland, Party Politics, 13(4), pp. 500-527, doi: 10.1177/1354068807075944.

McAllister, I. (1996) Leaders, In: LeDuc, L., Niemi, R. G. \& Norris, P. (eds.), Comparing democracies: elections and voting in global perspective (Thousand Oaks: Sage).

Mabileau, (1969) La personalisation du Pouvor dans les Gouvernements Democratiques, Revue Francaise de Science Politique, 10(1), pp. 39-65.

Michels, R. (1966) Political Parties. A Sociological Study of the Oligarchical Tendencies of Modern Democracy (New York: Free Press).

Montabes, J. (2002) Comportamiento electoral y sistema de partidos en Andalucía, In: Moyano, E. \& Pérez, M. (coords.) La Sociedad Andaluza (Córdoba: Instituto de Estudios Sociales de Andalucía), pp. 103-106.

Montabes, J. \& Rosado, E. (2000) Las elecciones municipales de 1999 en Andalucía: tendencias a la dualidad e voto, Paper prepared for the VII Convengo Internationale della Societá Italiana di Studi Elettorali, Elezioni locali e sistema de representanza in Italia e in Europa. Napoles (October, 20-23, 2000).

Montabes, J. \& Ortega, C. (2006) Las elecciones autonómicas en Andalucía: bases sociales y políticas del comportamiento electoral de los andaluces, In: Molins, J. \& Oñate, P. (eds.) Elecciones y Comportamiento Electoral en la España Multinivel (Madrid: CIS), pp. 137-164

Moser, R. \& Scheiner, E. (2005) Strategic Ticket Splitting and the Personal Vote in MixedMember Electoral Systems, Legislative Studies Quarterly 30(2), pp. 259-76.

Mughan, A. (2000) Media and the Presidentialization of Parliamentary Elections (New York: Palgrave).

Natera, A. (1997) Formas y Estilos de Liderazgo Local, In: Alba, C. \& Vanaclocha, F. (eds.) El Sistema Político Local: Un Nuevo Sistema de Gobierno (Madrid: Universidad Carlos III de Madrid y Boletín Oficial del Estado), pp. 113-140.

Natera, A. (2003) El liderazgo político en las sociedades democráticas (Madrid: Centro de Estudios Políticos y Constitucionales).

Ostrogorski, M. (1970) Democracy and the organization of political parties (New York; Haskell House).

Pillai, R. and Williams, E.A. (1996) Does leadership matter in the political arena? Voters perceptions of candidates' transformational and charismatic leadership and the 1996 U.S. presidential vote, Leadership Quarterly, 9(3), 397- 416, doi: 10.1016/S1048-9843(98)90038-8.

Poguntke, T \& Webb, P (2005). The Presidentialization of Politics in Democratic Societies, In: Poguntke, T. \& Webb, P. (eds.) The Presidentialization of Politics. A comparative Study of Modern Democracies (Oxford: Oxford University Press), pp 1-25.

Rico, G. (2002) Candidatos y electores: la popularidad de los líderes políticos y su impacto en el comportamiento electoral (Barcelona: Institut de Ciències Polítiques i Socials).

Robles, A. (2005) Líderes, partidos y seguidores. Las redes de apoyo partidistas, In: Natera, A. \& Vanaclocha, F. (eds.) Los liderazgos en el mercado politico y en la gestión pública (Madrid: Universidad Carlos III de Madrid), pp. 19-36. 
Ruscio, K P. (2004) The Leadership Dilemma in Modern Democracy (Cheltenham: Edward Elgar Publishing, Inc.).

Sartori G. (1989) Videopolitica, Revista Italian de scienza politica, 20(2) pp. 185-198.

Schudon, M. (1983) The News Media and the democratic process (New Cork: Aspen Institute for Humanistic Studies).

Shugart, M. S., Ellis Valdini, M. \& Suominen, K. (2005) Looking for Locals: Voter Information Demands and Personal Vote-Earning Attributes of Legislators under Proportional Representation, American Journal of Political Science, 49(2), pp. 437-449.

Trigo Pereira, P. \& Andrade e Silva, J. (2009) Citizens' freedom to choose representatives: Ballot structure, proportionality and "fragmented" parliaments, Electoral Studies, 28(1), pp. 101-110.

Vallés, J. M. \& Brugué, Q. (2001) El Gobierno Local, In: Alcántara, M. \& Martínez, A. (eds.) Política y Gobierno en España (Valencia: Tirant lo blanch), pp. 267-302.

Van Biezen, I. \& Hopkins, J. (2005) The Presidentialization of Spanish Democracy: Sources of Prime Ministerial Power in Post-Franco Spain, In: Poguntke, T. \& Webb, P. (eds.) The Presidentialization of Politics. A comparative Study of Modern Democracies (Oxford: Oxford University Press), pp 107-127.

Vanaclocha, F. (1997) Identidad de los Gobiernos Locales y Reforma Electoral, In: Alba, C. \& Vanaclocha, F. (eds.) El Sistema Político Local: Un Nuevo Sistema de Gobierno (Madrid: Universidad Carlos III de Madrid y Boletín Oficial del Estado), pp. 275-300.

Vanaclocha, F. (2005) Los liderazgos en el mercado electoral, In: A. Natera y F. Vanaclocha (dirs) Los liderazgos en el mercado político y en la gestión pública (Madrid: Universidad Carlos III), pp. 85-108.

Van der Brug, M. \& Mughan, A. (2007) Charisma, Leaders Effects and Support for RightWing Populist Parties, Party Politics, 13(1), pp. 29-51.

Van der Kolk, H. (2007) Local electoral systems in Western Europe, Local Government Studies, 33(2), pp. 159-180.

Wattemberg, M. (1991) The Rise of Candidate-Centred Politics: Presidential Elections in the 1980s (Cambridge, MA: Harvard University Press).

Weber, M. (1968) Economy and Society: An Outline of Interpretive Sociology (New York: Bedminster Press).

Wood, D. M. \& Norton, P. (1992) Do Candidates Matter? Constituency-Specific Vote: Changes for Incumbent MPs, 1983-1987, Political Studies 40(2), pp. 227-38, doi: 10.1111/j.1467-9248.1992.tb01381.x. 


\section{Appendix}

Table 1. Andalusian Electoral Participation. National, Regional and Local Election

\begin{tabular}{|c|c|c|c|c|c|c|c|c|c|c|c|c|c|c|c|c|c|c|c|c|c|c|c|}
\hline \multicolumn{3}{|c|}{ Almería } & \multicolumn{3}{|c|}{ Cadiz } & \multicolumn{3}{|c|}{ Cordoba } & \multicolumn{3}{|c|}{ Granade } & \multicolumn{3}{|c|}{ Huelva } & \multicolumn{3}{|c|}{ Jaen } & \multicolumn{3}{|c|}{ Malaga } & \multicolumn{3}{|c|}{ Seville } \\
\hline $\mathrm{N}$ & $\mathrm{R}$ & $\mathrm{L}$ & $\mathrm{N}$ & $\mathrm{R}$ & $\mathrm{L}$ & $\mathrm{N}$ & $\mathrm{R}$ & $\mathrm{L}$ & $\mathrm{N}$ & $\mathrm{R}$ & $\mathrm{L}$ & $\mathrm{N}$ & $\mathrm{R}$ & $\mathrm{L}$ & $\mathrm{N}$ & $\mathrm{R}$ & $\mathrm{L}$ & $\mathrm{N}$ & $\mathrm{R}$ & L & $\mathrm{N}$ & $\mathrm{R}$ & $\bar{L}$ \\
\hline 72.75 & 4.66 & 62.38 & 67.44 & 68.12 & 56.21 & 75.81 & 76.62 & 65.58 & 74.31 & 75.89 & 63.88 & 69.91 & 70.40 & 64.71 & 78.61 & 79.26 & 71.13 & 71.35 & 72.31 & 57.94 & 73.84 & 74.38 & 60.4 \\
\hline
\end{tabular}

Note: N= National elections held in March 2008; R= Regional elections held in March 2008; L= Local elections held in May 2007

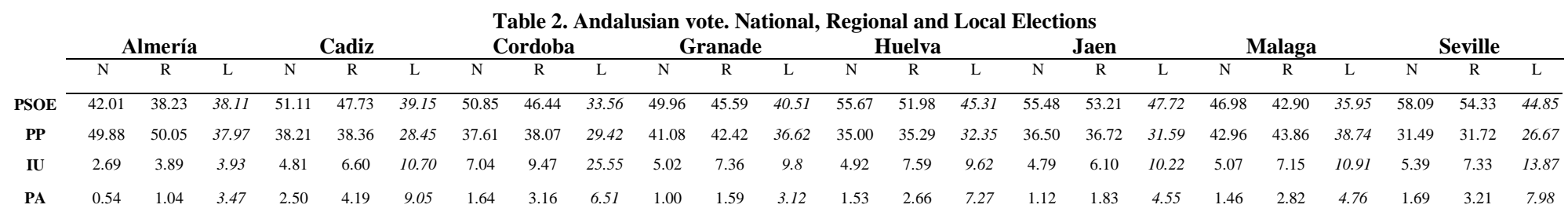

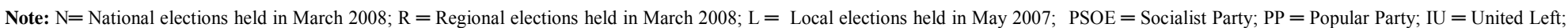
$\mathrm{PA}=$ Andalusian Party

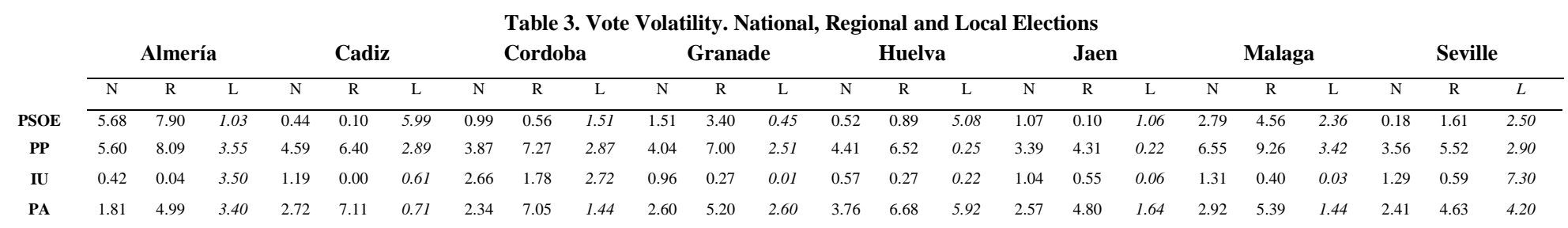

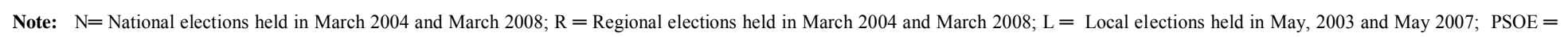
Socialist Party; PP = Popular Party 
G. Martinez Fuentes \& C. Ortega Villodres: The Political Leadership Factor in the Spanish Local Elections

Table 4

Results of Logistic Regression Analysis: Motivations of the PSOE and PP vote choice

Long-term

predisposition

predispositions

Short-term

predispositions

\begin{tabular}{|c|c|c|c|c|c|c|}
\hline & B & $\begin{array}{r}\text { PSOE } \\
\text { Exp } \\
\text { (B) }\end{array}$ & ote $\mathrm{B}^{*}$ & B & $\begin{array}{r}\text { PP } \\
\text { Exp } \\
\text { (B) }\end{array}$ & $\mathrm{B}^{*}$ \\
\hline $\begin{array}{l}\text { Party } \\
\text { identification } \\
\text { Ideological } \\
\text { proximity }\end{array}$ & $\begin{array}{l}-.956^{*} \\
-.176^{*} \\
\end{array}$ & .384 & -0.395 & $\begin{array}{l}-1.061 * \\
-.349 * \\
\end{array}$ & $\begin{array}{l}.346 \\
.705 \\
\end{array}$ & $\begin{array}{l}-.3743 \\
-.2106 \\
\end{array}$ \\
\hline Local economy & -.011 & .989 & -0.002 & .010 & 1.010 & .0020 \\
\hline $\begin{array}{l}\text { Regional } \\
\text { economy }\end{array}$ & -.142 & .867 & -0.033 & .017 & 1.017 & .0034 \\
\hline $\begin{array}{l}\text { National } \\
\text { economy } \\
\text { Local politics }\end{array}$ & -.100 & .905 & -0.021 & .229 & 1.257 & .0418 \\
\hline Regional politics & -.065 & .937 & -0.016 & -.178 & .837 & -.0371 \\
\hline National politics & -.219 & .803 & -0.056 & .126 & 1.134 & .0273 \\
\hline $\begin{array}{l}\text { Anti-terror } \\
\text { policy }\end{array}$ & $.435^{*}$ & 1.545 & 0.107 & .068 & 1.071 & .0142 \\
\hline
\end{tabular}

\section{Territorial}

policy

Andalusian

Statute

Corruption

scandals

Juana Chaos

Trial

$-.230 \quad .795$

1.169

Foreign Affairs

Illegalization of

\begin{tabular}{l} 
ANV \\
\hline PSOE nat.
\end{tabular}

campaign

PP nat.

Election

campaign

PSOE local

Campaign

campaign

PP local

$\begin{array}{llllll}.027 & 1.027 & 0.006 & -.400^{* *} & .671 & -.0839\end{array}$

$\begin{array}{llllll}-.043 & .958 & -0.010 & .249 & 1.282 & .0527\end{array}$

$\begin{array}{llllll}.042 & 1.043 & 0.085 & .297 * * * & 1.346 & .0672\end{array}$

(2)

1.286

$\begin{array}{lllllll}.252 & 1.286 & 0.0647 & -.285 & .752 & -.0617\end{array}$

$\begin{array}{llllll}-.046 & .955 & -0.010 & -.255 & .775 & -.0502\end{array}$

campaign

PSOE local

leader

$\begin{array}{llllll}-.063 & .939 & -0.015 & -.240 & .786 & -.0492\end{array}$

PP local leader

$\begin{array}{llllll}-.214 & .807 & -0.049 & .110 & 1.117 & .0214\end{array}$

PSOE regional

leader

PP regional

Party leaders

leader

PSOE national

leader

PP national

leader

Constant

$-.061$

$.941 \quad-0.015 \quad .337 * * \quad 1.401$

.0740

$\begin{array}{lllll}.642^{*} & .526 & -0.150 & .376^{*} & 1.457\end{array}$

.0739

$\begin{array}{llllll}.571 * & 1.770 & -1.184 * & -1.184 * & .306 & -.2602\end{array}$

$\begin{array}{llllll}.642 * & .526 & -0.150 & .376^{*} & 1.457 & .0739\end{array}$

$\begin{array}{llllll}.571 * & 1.770 & 0.148 & -1.184 * & .306 & -.2602\end{array}$

$\begin{array}{llllll}.168 * & 1.183 & 0.135 & -.103 & .902 & -.0712\end{array}$

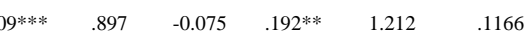

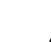

$\begin{array}{llllll}.042 & 1.043 & 0.034 & -.001 & .999 & -.0007\end{array}$

\begin{tabular}{cc}
$-.137^{*}$ & .872 \\
\hline $3.244^{*}$ & 25.62 \\
&
\end{tabular}

.872

$-0.114$

$\begin{array}{lll}.054 & 1.055 \quad .0393\end{array}$

$\mathrm{N}=1274$

-2log likelihood: 868,191

$\mathrm{R}^{2}$ Cox \& Snell: 0.50

$\mathrm{R}^{2}$ Nagelkerke: 0.670
$\mathrm{N}=1281$

-2log likelihood: 604,979

$\mathrm{R}^{2}$ de Cox \& Snell: 0.538

$\mathrm{R}^{2}$ Nagelkerke: 0.756

Note: $(*)$ The effects are significant at $\mathrm{P} \leq 0.001(* *)$ The effects are significant at $\mathrm{P} \leq 0.05$. $(* * *)$ The effects are significant at 0.10 or lower. 